\title{
Heteronomy in adolescent health: an integrative literature review
}

Flávia Pacheco de Araújo ${ }^{1}$

Aldo Pacheco Ferreira ${ }^{2}$

Marcos Besserman Vianna ${ }^{2}$

Maria Helena Barros de Oliveira ${ }^{2}$

${ }^{1}$ Escola de Enfermagem Anna Nery, Universidade Federal do Rio de Janeiro. R. Afonso Cavalcanti 275, Cidade Nova. 20071-003 Rio de Janeiro RJ Brasil. pacheco.flavia@gmail.com ${ }^{2}$ Grupo Direitos Humanos e Saúde, Escola Nacional de Saúde Pública Sérgio Arouca, Fiocruz. Rio de Janeiro RJ Brasil.

\begin{abstract}
Adolescents' health rights are not restricted to having their demands understood, but require their being respected as autonomous subjects and the agents of their own care. However, considering adolescents' rights in terms of their autonomy in the day-to-day of the health care service, the situation is precarious as a result of heteronomy, subjection of the individual to the will of others. A search for articles was conducted in the Scopus, PubMed and BVS databases, cross-referencing with the descriptors: "saude do adolescente" ("adolescent health"), "responsabilidade civil" ("civil responsibility") and "responsabilidade parental", ("parental responsibility”). After inclusion and exclusion criteria were applied, 32 studies were analysed. The results indicated that adolescents are generally not consulted in parents' or guardians' decision making about their health care, and also that the family relationship is established under rules maintained by punishment, accountability and control, while dialogue is neglected. In that light, there is a need for measures to protect and promote autonomy, while academic discussion of the relation between adolescent health and heteronomy, considering the fields of human rights and health, requires more in-depth evaluations with a view to providing legal guidance on parent's day-to-day role in adolescent health care.
\end{abstract}

Key words Adolescent, Health, Review 


\section{Introduction}

People develop in social environments, changing their participation in socio-cultural activities within communities that are also changing ${ }^{1}$. Nicola $^{2}$ writes "language, emotion, cognition and motor skills do not develop without the continuity of culture, which is provided by the social group".

Culture is certainly a complex construct and has been defined in various ways ${ }^{3}$. Definitions of culture tend to emphasise either the symbolic dimension, consisting in beliefs and doctrines that help people rationalise and give meaning to their lives, or behaviour (for example, parental styles) that is learned and transmitted from generation to generation ${ }^{4}$.

Culture can be considered the symbolic and behavioural product of human social life and social activity ${ }^{5}$, and culturally organised patterns of social interaction influence children's development ${ }^{6}$. The cultural experience, socialisation and the ability to occupy a place in groups are essential to mental health, work and relationships ${ }^{2}$.

Accordingly, the conception of diversity in society is permeated by stigmas, stereotypes and inequalities, which are constructed subjectively, historically, socially and culturally, by the community itself broadly and also by individual perceptions of differences, which relate to personal experiences, ethical and moral values, in short, people's life histories. These processes are interrelated and construct each other mutually and continuously ${ }^{7}$.

The term "heteronomy" derives from the Greek (hetero, meaning other, different; and nomia meaning law, rule) and can be defined as conduct or norm that does not proceed from reason or moral law. Consequently, heteronomy is the subjection of the individual to the will of third parties or a collectivity, deriving from neither reason nor moral laws, as a coercive imposition, external to the individual and independent of his or her will, the opposite of the autonomy of the moral norm". "Heteronomy" is thus intended to comprise all the principles of morality - education, civil constitution, feelings etc. - that individual will must submit to ${ }^{2}$. It means, therefore, that subjection to juridical rules is not dependent on the free will of those subject to them; on the contrary, there is external imposition that results in their obligatory nature ${ }^{7}$, and it is thus contrary to the concept of autonomy9.

The principle of autonomy reflects individuals' ability to deliberate and decide on matters that concern them, on the appropriateness and timeliness of acts that affect their interests, and to take responsibility for the consequences of those decision $s^{10}$. The assessment as to the consequences or risks of taking or not taking any given action is up to the individual directly affected by that action. The word "autonomy" also derives from the Greek (auto - I or self; nomos - law, rule, domain, government) and means self-government, self-determination, self-management. It connotes freedom, individual choice, free from coercion. That is, those who request and/ or receive an action, and are affected beneficially or not harmfully by it, know its value and it is they who should decide autonomously as to the suitability and timeliness of actions that affect them ${ }^{7,10}$.

Kant $^{11}$ points out that moral awareness evolved from heteronomy to autonomy. Thus, in the process of their development, individuals began to internalise family and social cultural norms from fear of punishment, as well as by observing positive models embodied in significant others, and that situation prospered to a higher level consisting in self-determination in accordance with moral principles and values that are justified by reason.

The Brazilian civil code stipulates that parents or legal guardians are responsible for their underage children, who are classified as incapable of expressing their will. That stipulation is overturned objectively when the child comes of age, and also by certain factors. It can be reversed: by the parents, or one of them in the absence of the other, by public instrument, independently of judicial authorisation, or by the sentence of a judge, after hearing the tutor, if the minor is fully sixteen years old; by the minor's marriage or occupying public employment; by their graduating from a course in higher education; by their civil or commercial establishment, or by the existence of an unemployment relationship, providing that, as a result of these, the sixteen year old minor has independent economic means ${ }^{12}$.

However, not all individuals have wills, which are regulated by the interplay between majority and minority. Entry into adult life brings with it conflicts in situations that involve the right to autonomy, privacy, confidentiality and the exercise of sexuality. This perspective was described in Kant's philosophy and deployed, in the Law field, for instance, by the Brazilian civil code ${ }^{8}$. This means that on certain matters of civil life, adolescents can exercise their autonomy, ending the heteronomy stipulated to be their parents' duty. 
In this regard, heteronomy may be relative when it applies to adolescents over 16 years old, thus undermining age as the predominant consideration in determining autonomy.

As mentioned above, adolescents' health is a question of human rights and, accordingly, requires the engagement of social entities, health managers and health personnel, family and society in understanding the demands of this population group, as well as the environmental, social and cultural factors that surround it, with a view to planning, developing and organising comprehensive healthcare ${ }^{13}$.

As a result, and particularly in health matters, autonomy constitutes a right of adolescents ${ }^{13}$ that is limited by the provisions of the Brazilian civil code. With regard to care for adolescents, Article 103 of the Medical Code of Ethics regulates principles regarding privacy (characterised by denying permission for another person in the appointment setting), confidentiality (the information discussed during and after the appointment may not be passed on the parents or guardians without the adolescent's assent) and secrecy. Here, one could add the right to autonomy, contained in Chapter II, Art. 17, of Brazil's Child and Adolescent Statute (ECA) ${ }^{14}$.

Adolescents' rights to comprehensive health care, youth participation in health decision making, autonomy, citizenship and ethics and so on are all integral to Brazil's public health policy ${ }^{13}$. Accordingly, from 18 years of age, these adolescents are civilly responsible for themselves. Adolescents under 18 years of age, however, under Brazil's current civil code, are the responsibility of their parents and/or legal guardians. This poses questions: can health personnel obey adolescents decisions during the care process if they are contrary to the opinions of their parents and/or guardians? If they do so, does public health policy support these professionals?

Given these questions, this study aimed to identify and analyse the scientific production on heteronomy towards adolescents in health matters. However, this article is not intended to answer those questions, but to enter into the subject in depth in order to clarify them. It will, however, serve as input to thinking about these dilemmas which arise in ethical and legal form in the daily activities of health personnel providing care to adolescents, and encourage discussion of this subject in the field of human rights and health by interrelating these fields of knowledge.

\section{Methodology}

In order to trace an overall panorama of studies involving adolescence, parents and civil responsibility, an integrative literature review was conducted $^{15}$. The review was guided by the Preferred Reporting Items for Systematic Reviews and Meta-Analyses (PRISMA) ${ }^{16}$.

The review was performed between August and October 2017 in the Scopus, Publisher Medline (PubMed) and Biblioteca Virtual de Saúde (BVS) data bases. The search strategy used the following descriptors: saúde do adolescente (adolescent health), responsabilidade civil (civil responsibility) and responsabilidade parental (parental responsibility), combined by the Boolean operators OR and AND. For the Pubmed search, the descriptors were identified in the Medical Subject Headings (Mesh), available in the U.S. National Library of Medicine (http://www.nlm. nih.gov/mesh/), using the search expression: ("adolescent health"[MeSH Terms]) AND “damage liability"[MeSH Terms]) AND (“adolescent health" [MeSH Terms]) AND “parenting” [MeSH Terms]). For the BVS search, the descriptors were identified in the Descriptors em Ciências da Saúde (DeCS), available in the Biblioteca Virtual em Saúde (http://decs.bvs.br) and, respectively, the search expressions: (tw:(damage liability)) AND (tw:(adolescent health)) and (tw:(parenting)) AND (tw:(adolescent health)). Publication date was limited to articles since 2000.

The Scopus data base was chosen for its multidisciplinary nature. The "All Fields" option was selected. In the "Document Type" section, it was decided to include only articles ("article"). PubMed was chosen because it is currently one of the leading research sources in the health field. The following advanced search filters were chosen: "All Fields" and, in the "Article Type", only "Journal Article". The Biblioteca Virtual em Saúde (BVS) was chosen for its Brazilian national scope. It was searched using Todos os Índices (All Indexes), Método Integrado (Integrated Method) and Todas as Fontes (All Sources): Medline and Lilacs. The only filter used was Tipo de Documento (Document Type), because only Artigos (Articles) was selected.

The inclusion criteria for articles were: full article, in Portuguese, Spanish or English, available free of charge by digital means from the data bases above, with publication date between 2000 and 2016. The exclusion criteria were: articles repeated in more than one data base and articles not meeting the study goals. 
The kappa coefficient of agreement was calculated at 0.85 , suggesting excellent agreement between the researchers ${ }^{17}$. Disagreements were resolved by consensus between the two evaluators. After selecting the articles, data were extracted according to a protocol established in advance by the authors and were tabulated using Microsoft Office Excel 2013.

The articles were evaluated for quality against the STROBE initiative check-list, as translated by Malta et al. ${ }^{18}$, which contains 22 items relating to the essential points that should be described in observational studies. Each item scored from 0 to 1 and articles that achieved a 50\% score (11 points) were considered of good quality.

At first, 2448 studies were identified, of which 2198 failed to meet the inclusion criteria, leaving 250 articles for analysis; of these, 32 addressed the study question and formed part of this review (Figure 1). The articles were selected by two researchers separately, in three stages, by reading the title, the abstract and then the full article. In data analysis of the included articles, the following information was extracted: 1) authorship and year; 2) country of publication; 3) methodology used; 4) characteristics of the sample; and 5) evaluation instruments used.

\section{Results}

In all, 2448 articles on adolescents, parental responsibility and heteronomy were found in the data bases searched on the search strategies applied. Table 1 shows the number of articles identified in each data base using the keyword combinations.

Chart 1 shows the main features - authorship, year of publication, country of study, method used, number of participants (sample) and instruments used to evaluate the study variables - of the 32 studies evaluating adolescent health, civil responsibility and parental responsibility, which were selected for this review. The studies were considered of good quality, in accordance with the instrument applied (STROBE proto$\mathrm{col})^{18}$, if they exceeded $50 \%$ of positive scores among the items listed in the evaluation parameters.

As regards country and year of publication, the United States $(n=9)^{19-27}$, followed by England $(\mathrm{n}=6)^{28-33}$ and Brazil $(\mathrm{n}=6)^{34-39}$, stood out as the countries where most articles were produced on the study subject, and all were published between 2004 and 2017. The sample size varied

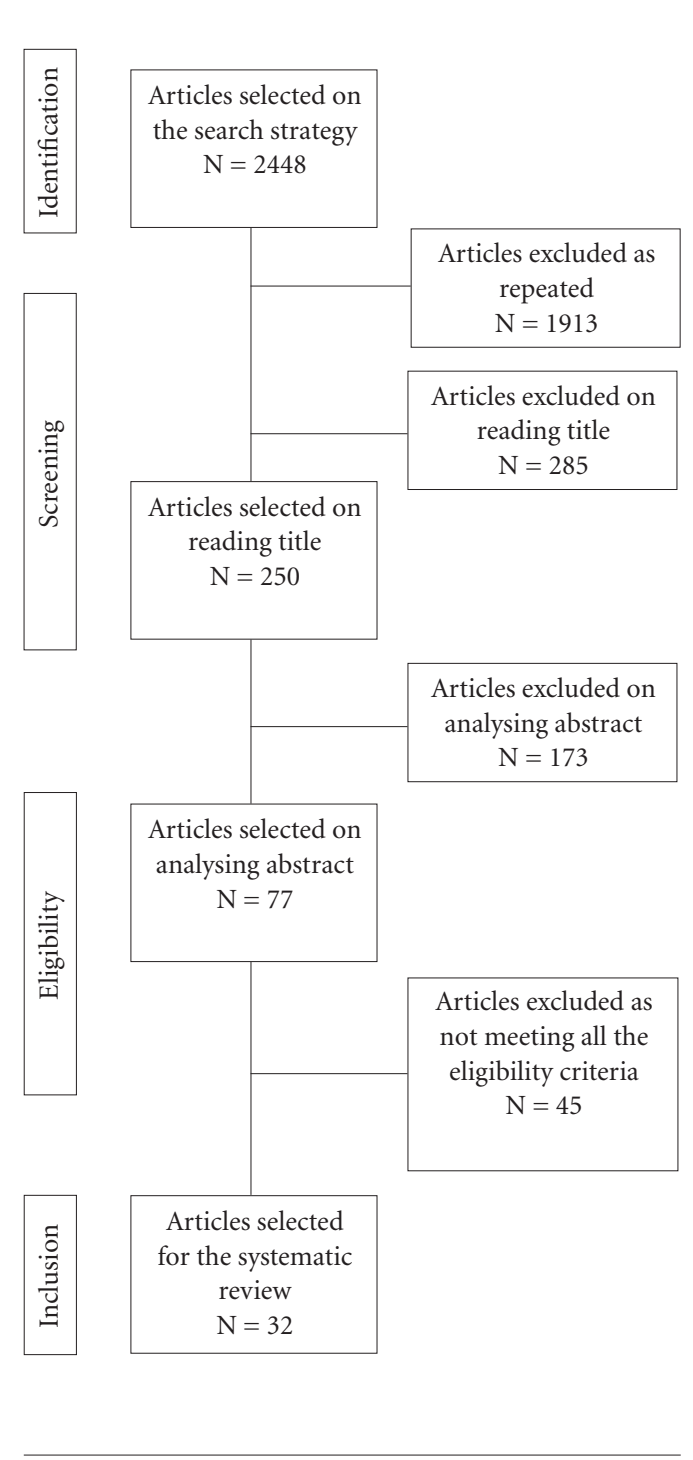

Figure 1. Flow diagram of the process of identifying and selecting publications for exclusion, 2000 to 2017.

Table 1. No. Publications found in each data base

\begin{tabular}{lccrr}
\multicolumn{1}{c}{ Sets } & Scopus & Pubmed & BVS & Total \\
\hline $\begin{array}{l}\text { "damage liability" } \\
\text { AND "adolescent }\end{array}$ & 8 & 2 & 7 & 17 \\
$\begin{array}{l}\text { health" } \\
\text { "parenting" AND } \\
\text { "adolescente health" }\end{array}$ & 251 & 1068 & 1112 & 2431 \\
Total & 259 & 1070 & 1119 & 2448 \\
\hline
\end{tabular}


Chart 1. Studies of heteronomy in adolescent health

\begin{tabular}{|c|c|c|c|c|}
\hline Reference (Year) & Country & Method & Sample & Instruments \\
\hline $\begin{array}{l}\text { Bello et al. } \\
(2017)^{48}\end{array}$ & $\begin{array}{l}\text { Nigeria, } \\
\text { Kenya }\end{array}$ & $\begin{array}{l}\text { Longitudinal } \\
\text { and qualitative }\end{array}$ & $\begin{array}{l}\text { Sixty-six girls and } \\
\text { boys ( } 11 \text { - } 13 \text { years })\end{array}$ & $\begin{array}{l}\text { Adolescents' and parents' reactions } \\
\text { to puberty. } \\
\text { Intercultural and intergenerational } \\
\text { comparison. }\end{array}$ \\
\hline $\begin{array}{l}\text { Khatun et al. } \\
(2017)^{49}\end{array}$ & Australia & $\begin{array}{l}\text { Observational } \\
\text { (cohort) }\end{array}$ & 2643 mothers & $\begin{array}{l}\text { Child development. } \\
\text { Intelligence tests. } \\
\text { Mothers/psychology. } \\
\text { Teenage pregnancy. } \\
\text { Family power. } \\
\text { Young adults. }\end{array}$ \\
\hline Lin \& Seo $(2017)^{19}$ & USA & $\begin{array}{l}\text { Longitudinal } \\
\text { and qualitative }\end{array}$ & $\begin{array}{l}79,601 \text { (parents or } \\
\text { guardians) }\end{array}$ & $\begin{array}{l}\text { Interviews of parents or guardians } \\
\text { with children from } 0-17 \text { years old. } \\
\text { Specific questionnaire. }\end{array}$ \\
\hline $\begin{array}{l}\text { Rapp et al. } \\
(2017)^{28}\end{array}$ & England & Longitudinal & $\begin{array}{l}551 \text { ( } 316 \text { boys, } 235 \\
\text { girls })(8-12 \text { years old })\end{array}$ & $\begin{array}{l}\text { KIDSCREEN-52 quality of life } \\
\text { questionnaire. }\end{array}$ \\
\hline $\begin{array}{l}\text { Steinke et al. } \\
(2017)^{20}\end{array}$ & USA & Qualitative & $\begin{array}{l}92 \text { adolescents (15-19 } \\
\text { years old) }\end{array}$ & $\begin{array}{l}\text { Sexual behaviour. Semi-structured } \\
\text { interview. }\end{array}$ \\
\hline Tu et al. $(2017)^{29}$ & England & Qualitative & 176 adolescents & British Columbia Children's Hospital \\
\hline $\begin{array}{l}\text { Verberne et al. } \\
(2017)^{41}\end{array}$ & Holland & $\begin{array}{l}\text { Qualitative- } \\
\text { inductive } \\
\text { thematic } \\
\text { analysis }\end{array}$ & $\begin{array}{l}42 \text { parents and } 24 \\
\text { children }\end{array}$ & $\begin{array}{l}\text { Family balance. } \\
\text { Parental care. } \\
\text { Paediatric palliative care. } \\
\text { Home care. }\end{array}$ \\
\hline $\begin{array}{l}\text { Zilanawala et al. } \\
(2017)^{30}\end{array}$ & England & $\begin{array}{l}\text { Observational } \\
\text { (cohort) }\end{array}$ & $\begin{array}{l}19,244 \text { families of } \\
\text { children born in the } \\
\text { United Kingdom } \\
\text { between } 2000 \text { and } \\
2002\end{array}$ & UK Millennium Cohort Study. \\
\hline $\begin{array}{l}\text { Cheng \& Powell } \\
(2015)^{21}\end{array}$ & USA & Qualitative & 236 participants & $\begin{array}{l}\text { New Family Structures Study } \\
\text { (NFSS). }\end{array}$ \\
\hline $\begin{array}{l}\text { Chiang et al. } \\
(2015)^{34}\end{array}$ & Brazil & Qualitative & $\begin{array}{l}30 \text { parents (father or } \\
\text { mother) }\end{array}$ & $\begin{array}{l}\text { Semi-structured interview with a } \\
\text { demographic section and qualitative } \\
\text { questions (disease prevention } \\
\text { methods, anti-HPV vaccine and } \\
\text { vaccines in general). }\end{array}$ \\
\hline $\begin{array}{l}\text { Cianchetti et al. } \\
(2015)^{42}\end{array}$ & Italy & $\begin{array}{l}\text { Observational, } \\
\text { multicentre } \\
\text { study }\end{array}$ & $\begin{array}{l}324 \text { pre-adolescents } \\
\text { and adolescents ( } 3-17 \\
\text { years old) ( } 164 \text { girls } \\
\text { and } 160 \text { boys) }\end{array}$ & $\begin{array}{l}\text { Quality of Life questionnaire. } \\
\text { QOLIE-AD-48 questionnaire. }\end{array}$ \\
\hline $\begin{array}{l}\text { Colver et al. } \\
(2015)^{31}\end{array}$ & England & $\begin{array}{l}\text { Longitudinal, } \\
\text { cross-sectional }\end{array}$ & $\begin{array}{l}818 \text { children }(8-12 \\
\text { years old })\end{array}$ & $\begin{array}{l}\text { Quality of life questionnaire. } \\
\text { SPARCLE1 questionnaire } \\
\text { (children). } \\
\text { SPARCLE2 questionnaire } \\
\text { (adolescent). }\end{array}$ \\
\hline $\begin{array}{l}\text { Roberts et al. } \\
(2015)^{22}\end{array}$ & USA & Longitudinal & 8882 women & $\begin{array}{l}\text { Questionário Childhood Trauma. } \\
\text { Questionário Symptoms Scale of the } \\
\text { McK-night Risk Factor Survey. }\end{array}$ \\
\hline $\begin{array}{l}\text { Terres-Trindade } \\
\& \text { Mosmann } \\
(2015)^{35}\end{array}$ & Brazil & Qualitative & $\begin{array}{l}200 \text { youth }(15-24 \\
\text { years old) }\end{array}$ & $\begin{array}{l}\text { Internet dependence in youth. } \\
\text { Specific questionnaire. }\end{array}$ \\
\hline
\end{tabular}


Chart 1. Studies of heteronomy in adolescent health

\begin{tabular}{|c|c|c|c|c|}
\hline Reference (Year) & Country & Method & Sample & Instruments \\
\hline $\begin{array}{l}\text { Zeiders et al. } \\
(2015)^{23}\end{array}$ & USA & Longitudinal & $\begin{array}{l}189 \text { families of } \\
\text { Mexican origin }\end{array}$ & $\begin{array}{l}\text { Analysis of intergenerational } \\
\text { processes among grandmothers, } \\
\text { adolescent mothers and their } \\
\text { children. }\end{array}$ \\
\hline $\begin{array}{l}\text { Barbosa \& Wagner } \\
(2014)^{36}\end{array}$ & Brazil & Focal group & 15 adolescents & $\begin{array}{l}\text { Space for discussion and } \\
\text { construction of meaning for access } \\
\text { to each adolescent's life experience } \\
\text { and idiosyncrasies. }\end{array}$ \\
\hline Beilby $(2014)^{50}$ & Australia & Qualitative & $\begin{array}{l}10 \text { children who } \\
\text { stutter with } 20 \text { parents } \\
10 \text { children who do } \\
\text { not stutter with their } \\
\text { parents }\end{array}$ & $\begin{array}{l}\text { Multidimensional approach to } \\
\text { stuttering. } \\
\text { Overall Assessment of Speakers' } \\
\text { Experience of Stuttering-Standard } \\
\text { Interview (OASES ) questionnaire. }\end{array}$ \\
\hline $\begin{array}{l}\text { Brody et al. } \\
(2014)^{40}\end{array}$ & Africa & Longitudinal & $\begin{array}{l}368 \text { pre-adolescents } \\
(11-13 \text { years old })\end{array}$ & $\begin{array}{l}\text { Prospective relations of harsh } \\
\text { parenting during pre-adolescence, } \\
\text { anger in adolescence and a health } \\
\text { phenotype in late adolescence. }\end{array}$ \\
\hline Faler et al. $(2013)^{37}$ & Brazil & Case-control & $\begin{array}{l}431 \text { adolescents (14-16 } \\
\text { years old) }\end{array}$ & $\begin{array}{l}\text { Pregnancy in adolescence. } \\
\text { Consumption of alcoholic } \\
\text { beverages. } \\
\text { Habit of smoking. } \\
\text { Illicit drugs. }\end{array}$ \\
\hline Lee et al. $(2013)^{43}$ & Thailand & $\begin{array}{l}\text { Quantitative- } \\
\text { qualitative }\end{array}$ & 215 children with HIV & Parent-child relations. \\
\hline $\begin{array}{l}\text { Monte \& Sampaio } \\
(2013)^{38}\end{array}$ & Brazil & Qualitative & $\begin{array}{l}17 \text { socio-educators } \\
29 \text { adolescents }\end{array}$ & $\begin{array}{l}\text { Interviews. } \\
\text { Specific questionnaire. }\end{array}$ \\
\hline $\begin{array}{l}\text { Perrin et al. } \\
(2013)^{24}\end{array}$ & USA & Qualitative & 3000 participants & $\begin{array}{l}\text { New Family Structures Survey } \\
\text { (NFSS). }\end{array}$ \\
\hline $\begin{array}{l}\text { Rodenburg et al. } \\
(2013)^{44}\end{array}$ & Holland & $\begin{array}{l}\text { Quantitative- } \\
\text { qualitative }\end{array}$ & 73 children & Parenting. \\
\hline $\begin{array}{l}\text { Franić et al. } \\
(2012)^{47}\end{array}$ & Croatia & Longitudinal & 695 adolescents & $\begin{array}{l}\text { Children's Depression Inventory } \\
\text { (CDI). } \\
\text { World Health Organization survey. } \\
\text { Health Behavior in School-aged } \\
\text { Children. }\end{array}$ \\
\hline $\begin{array}{l}\text { Nelson et al. } \\
(2012)^{32}\end{array}$ & England & Qualitative & $\begin{array}{l}35 \text { parents with young } \\
\text { children }\end{array}$ & $\begin{array}{l}\text { Elective surgery. } \\
\text { Parents. } \\
\text { Children. } \\
\text { Specific questionnaire. }\end{array}$ \\
\hline Regnerus $(2012)^{25}$ & USA & $\begin{array}{l}\text { Longitudinal, } \\
\text { qualitative }\end{array}$ & $\begin{array}{l}39 \text { adolescents with } \\
\text { same-sex parents }\end{array}$ & New family structures. \\
\hline $\begin{array}{l}\text { Freitas \& Seidl } \\
(2011)^{39}\end{array}$ & Brazil & $\begin{array}{l}\text { Qualitative, } \\
\text { descriptive }\end{array}$ & $\begin{array}{l}10 \text { women }(29-57 \\
\text { years old })\end{array}$ & Specific questionnaire. \\
\hline $\begin{array}{l}\text { Parvizy \& Ahmadi } \\
(2009)^{46}\end{array}$ & Iran & $\begin{array}{l}\text { Qualitative, } \\
\text { descriptive }\end{array}$ & $\begin{array}{l}41 \text { adolescents (11-19 } \\
\text { years old) }\end{array}$ & $\begin{array}{l}\text { Profiling parental knowledge of } \\
\text { adolescent health risk factors and } \\
\text { characteristics. }\end{array}$ \\
\hline $\begin{array}{l}\text { Kamon et al. } \\
(2006)^{26}\end{array}$ & USA & Qualitative & $\begin{array}{l}149 \text { parents of } \\
\text { adolescent marijuana } \\
\text { dependents (12-18 } \\
\text { years old) }\end{array}$ & $\begin{array}{l}\text { Child Behavior Checklist (CBCL). } \\
\text { Youth Self-Report (YSR). }\end{array}$ \\
\hline $\begin{array}{l}\text { Roelofs et al. } \\
(2006)^{45}\end{array}$ & Holland & Qualitative & $\begin{array}{l}237 \text { adolescents (9-12 } \\
\text { years old) }\end{array}$ & $\begin{array}{l}\text { Anxiety. Depression. } \\
\text { Aggression. }\end{array}$ \\
\hline
\end{tabular}


Chart 1. Studies of heteronomy in adolescent health

\begin{tabular}{|l|l|l|l|l|}
\hline Reference (Year) & Country & \multicolumn{1}{|c|}{ Method } & \multicolumn{1}{|c|}{ Sample } & \multicolumn{1}{c|}{ Instruments } \\
\hline $\begin{array}{l}\text { Friedlaender et al. } \\
(2005)^{27}\end{array}$ & USA & Case-control & 157 children & $\begin{array}{l}\text { Bio-behavioural intervention. } \\
\text { Adverse childhood experiences. } \\
\text { Attention deficit/hyperactivity } \\
\text { disorder. } \\
\text { Cognitive-behavioural therapy. } \\
\text { Father-child interaction therapy. } \\
\text { Post-traumatic stress syndrome. } \\
\text { Trauma-focussed cognitive- } \\
\text { behavioural therapy. }\end{array}$ \\
\hline Saltzburg $(2004)^{33}$ & England & Qualitative & $\begin{array}{l}5 \text { mothers and 2 } \\
\text { fathers }\end{array}$ & $\begin{array}{l}\text { Phenomenological psychology } \\
\text { approach. } \\
\text { Specific questionnaire. }\end{array}$ \\
\hline
\end{tabular}

significantly depending on whether the research considered adolescents, pre-adolescents and children, or included also parents, mothers or guardians, and sexual preferences. As concerns study characteristics, most of the publications used qualitative procedures and cross-sectional evaluations as their approach.

\section{Discussion}

Adolescents' rights, as regards their autonomy in day-to-day health care, operate against a background of heteronomy, the subjection of the individual to the will of others ${ }^{33,36,40}$. Adolescents rights in health matters are not restricted to having their demands understood, but entail their being respected as autonomous subjects and agents of their own care ${ }^{7}$. However, attitudes among health personnel continue to favour guardians and/or parents to the detriment of adolescents ${ }^{22,34}$. Care by professionals in approaching others, even given the latter's limitations, may make the difference between their ignoring the subject in all its pre-eminence or respecting its reservation of the independent right to decide.

The authors have observed this in the course of their professional activities in care provision for adolescents, in both primary and hospital settings ${ }^{19,28,31,32,34,40-45}$ and in the school environment ${ }^{35,46}$. In institutional health care settings, health personnel's efforts to engage adolescents' participation during the care process were unassertive as compared with the participation of their guardians and/or parents. In the school environment, adolescents appeared as the central figures in care and participated actively in selfcare.
In law, adolescents have gained comprehensive protection by society, the State and their parents, with health care forming an integral part of that context. This has highlighted the need to address the demands of this population and to respect its specific social, cultural, economic and other characteristics ${ }^{25-27,32,33,36-39,46,47}$. This corresponds to adolescents' rights, among which is the right to autonomy, to make the decisions and choices that will orient the interpersonal relationships established with the adolescents. This is especially true in health matters, where the underlying guiding principle is the humanisation of care $^{23,36,43,44}$.

The studies address parents' responsibility for adolescent health and for establishing what they should and should not do. This asserts heteronomy in relation to adolescents in health matters and disregards their desires, choices and wishes, which are constituent components of autonomy. This difference in attitudes may be justified by an adolescent's state of health, but even adolescents in frail state of health should be respected in the health centre or hospital environment by attentive listening for their needs, demands and wishes. Another issue observed in professional activities was academics' questioning of the contradiction between autonomy and heteronomy in relation to adolescents' self-care management.

Another motivator for the study was the issue of culture. This was perceived, for example, in parents' decision to vaccinate their children against the human papillomavirus (HPV), which was taken out of fear - in view public health hazards - that they contract diseases, in addition to Brazilian parents' deep-rooted cultural memory of the importance of vaccination ${ }^{34}$. Note that the parents' decisions were not grounded in knowl- 
edge about the vaccine, because many of them did not know the meaning of HPV, how it is transmitted or the disease it may cause, in addition to connecting it with the human immunodeficiency virus (HIV) ${ }^{43}$.

The Brazilian Civil Code's classification of adolescents as relatively or absolutely incapable means that, from the legal viewpoint, a portion of Brazil's population fails to display the ability to express its wishes or to act. This limitation rests on the age factor, with life experience setting the seal on autonomy ${ }^{7,12}$. Indeed, it was also observed that the autonomy of children, the mentally disabled and others is reduced, either permanently or temporarily, because they are considered incapable of self-management ${ }^{31,39}$.

In view of the discussion presented here, it can be inferred that parents' or guardians' decision making is generally a complex, solitary act influenced by cultural factors, common sense, scientific knowledge, life experience and so on. Thus, little consideration is given to adolescent's desires or wishes, and is observed in only a few studies $^{27,45}$. In that light, parents constitute agents of heteronomy, while they should be facilitators for adolescents in exercising their autonomy, enabling them to decide for themselves by providing information, thinking together on possible paths and, ultimately, giving a voice to those decisions.

In that regard, parents and/or legal guardians should seek to dialogue with adolescents about their health issues and consider their opinions, desires and wishes, with a view to fulfilling their parental responsibility, as provided for in $\operatorname{law}^{13}$. When this is aligned with the development of self-control, by involving adolescents in self-reflection practices, such as observing their own actions (self-monitoring), knowing whether or not their behaviour is acceptable (self-assessment) and thus affording self-reliance, it is rewarded by realising acceptable behaviour ${ }^{11}$.

The family gives the context where the human person is constructed and develops in the interpersonal relation established among its members. Therefore, that space presents rules to be followed for the sake of harmonious coexistence. As regards relations between parents and adolescents, the construction of rules can be prescribed by parents and negotiated with the adolescents to the extent they consider appropriate to their children's development and maturity ${ }^{6}$.

Adolescence is a phase made up of psychological, emotional, social and physical changes. On the one hand, it is a time of seeking independence from parents and gaining autonomy, but also of belonging to groups of peers and defining personality. At many times, adolescents are treated as inconsequent and irresponsible, but they need recognition of their rights as citizens and agents of their own lives and health.

That is why it is necessary to build an environment of dialogue, particularly in adolescents' family contexts, with a view to fostering participation by these subjects. Accordingly, punitive, enforcement and control measures may not be effective.

Recognising adolescents as subjects with rights, that is, as citizens, will enhance the formation of participating adults who exercise autonomy, because they will have developed critical thinking and a sense of responsibility and cooperation during this phase of change and formation, which will also contribute to their self-esteem and the formation of a life project.

\section{Conclusion}

In view of this study, even considering its limitations, academic discussion of the relation between adolescent health and heteronomy needs to be pursued in greater depth in the Law and Health fields, particularly with a view to providing legal guidance for everyday professional activities during care for adolescent health.

During their training, most health professionals learn and grasp the ethical need to respect concrete others as citizens and to safeguard their dignity. Not only is it an obligation of public health to value and respect adolescents as full citizens, this should be enhanced to ensure that they participate in their own health condition.

Legally, however, adolescents are considered absolutely or relatively incapable, and it is up to their parents and/or legal guardians to protect them comprehensively, because it is impossible for them to take responsibility for their acts given the immaturity attendant on their age.

This poses a dilemma in everyday health care activities, because - as shown in this study - parents may take intractable attitudes, which disregard the opinions, desires and wishes of their adolescent children in all manner of life contexts, especially in health matters, thus reproducing, in the health context, the everyday family situation based on punishment, control and enforcement by parents in order to maintain the rules, but not engaging in dialogue to that end.

Meanwhile, efforts should be made to seek more research into adolescents' day-to-day fami- 
ly contexts in order to understand how relations between parents and children are established, because these can influence parents' decision making about adolescents' access to health. Also, discussions should be pursued on relevant themes, in both the Law and Health fields, as in this study, because those contexts need to be considered through these two lenses.
That concern is warranted by possible problematical situations, such as disagreement between parents and their adolescent children over health matters. In such situations, health professionals must consider the adolescents' position ethically, while recognising parental responsibility in view of their children's legally stipulated incapacity.

\section{Collaborations}

FP Araújo worked on design, research, methodology and final writing. AP Ferreira and MB Vianna worked on research, methodology and final writing. MHB Oliveira worked on research and final writing. 


\section{References}

1. Rogoff B. The cultural nature of human development. Oxford: Oxford University Press; 2003.

2. Nicola U. Antologia Ilustrada de Filosofia: das origens à idade moderna. São Paulo: Ed. Globo; 2005.

3. Kroeber AL, Kluckhohn C, Untereiner W. Culture: A Critical review of concepts and definitions. New York: Vintage; 1952.

4. Shweder RA, Goodnow JJ, Hatano G, LeVine RA, Markus HR, Miller PJ. The cultural psychology of development: One mind, many mentalities. In: Damon W, Lerner RM, editors. Handbook of Child Psychology: Theoretical models of human development. Hoboken: Wiley; 2006. p. 716-792.

5. Wertsch JV, Tulviste P. LS Vygotsky and contemporary developmental psychology. $2^{\text {nd }}$ ed. In: Daniels H. An introduction to Vygotsky. London: Routledge; 2005. p. 59-80.

6. Vygotsky LS. Handbook of child psychology. In: Kessen W, editor. History, theory, and methods. Hoboken: Wiley; 1981.

7. Freitas AF. Estudo sobre a heteronomia na assistência em saúde a crianças e adolescentes com necessidades especiais [dissertação]. Brasília: Universidade de Brasília; 2010.

8. Bresolin K. Autonomia versus heteronomia: o princípio da moral em Kant e Levinas. Conjectura: Filos. Educ. 2013; 18(3):166-183.

9. Fleury-Teixeira P, Vaz FAC, Campos FCC, Álvares J, Aguiar RAT, Oliveira VA. Autonomia como categoria central no conceito de promoção de saúde. Cien Saude Colet 2008; 13(Supl. 2):2115-2122.

10. Reichert CB. Autonomia na adolescência e sua relação com os estilos parentais [tese]. Porto Alegre: Pontifícia Universidade Católica; 2006.

11. Kant I. Fundamentação da metafísica dos costumes. São Paulo: Companhia Editorial Nacional; 1964.

12. Brasil. Lei no 10.406 , de 10 de janeiro de 2002. Código Civil. Diário Oficial da União 2002; 11 jan.

13. Brasil. Ministério da Saúde (MS). Diretrizes nacionais para a atenção integral à saúde de adolescentes e jovens na promoção, proteção e recuperação da saúde. Brasília: MS; 2010.

14. Brasil. Lei $n^{\circ} 8.069$, de 13 de julho de 1990. Estatuto da Criança e do adolescente. Diário Oficial da União 1990; 27 set.

15. Souza MT, Silva MD, Carvalho R. Revisão integrativa: $o$ que é e como fazer. Einstein 2010; 8(1):102-106.

16. Liberati A, Altman DG, Tetzlaff J, Mulrow C, Gotzsche PC, Ioannidis JP, Clarke M Devereaux PJ, Kleijnen J, Moher D. The PRISMA statement for reporting systematic reviews and meta-analyses of studies that evaluate healthcare interventions: explanation and elaboration. BMJ 2009; 339:b2700.

17. Landis JR, Koch GG. The measurement of observer agreement for categorical data. Biometrics 1997; 33(1):159-174.
18. Malta M, Cardoso LO, Bastos FI, Magnanini MM, Silva CM. STROBE initiative: guidelines on reporting observational studies. Rev Saude Publica 2010; 44(3):559565.

19. Lin YC, Seo DC. Cumulative family risks across income levels predict deterioration of children's general health during childhood and adolescence. PLoS One 2017; 12(5):e0177531.

20. Steinke J, Root-Bowman M, Estabrook S, Levine DS, Kantor LM. Meeting the needs of sexual and gender minority youth: formative research on potential digital health interventions. J Adolesc Health 2017; 60(5):541548.

21. Cheng S, Powel B. Measurement, methods, and divergent patterns: Reassessing the effects of same-sex parents. Soc Sci Res 2015; 52:615-626.

22. Roberts AL, Chen Y, Slopen N, McLaughlin KA, Koenen KC, Austin SB. Maternal experience of abuse in childhood and depressive symptoms in adolescent and adult offspring: a 21-year longitudinal study. Depress Anxiety 2015; 32(10):709-719.

23. Zeiders KH, Umaña-Taylor AJ, Jahromi LB, Updegraff KA. Grandmothers' familism values, adolescent mothers' parenting efficacy, and children's well-being. J Fam Psychol 2015; 29(4):624-634.

24. Perrin AJ, Cohen PN, Caren N. Are children of parents who had same-sex relationships disadvantaged? A scientific evaluation of the no-differences hypothesis. Journal of Gay \& Lesbian Mental Health 2013; 17(3):327-336.

25. Regnerus M. How different are the adult children of parents who have same-sex relationships? Findings from the new family structures study. Soc Sci Res 2012; 41(4):752-770.

26. Kamon JL, Stanger C, Budney AJ, Dumenci L. Relations between parent and adolescent problems among adolescents presenting for family-based marijuana abuse treatment. Drug Alcohol Depend 2006; 85(3):244-254.

27. Friedlaender EY, Rubin DM, Alpern ER, Mandell DS, Christian CW, Alessandrini EA. Patterns of health care use that may identify young children who are at risk for maltreatment. Pediatrics 2005; 116(6):1303-1308.

28. Rapp M, Eisemann N, Arnaud C, Ehlinger V, Fauconnier J, Marcelli M, Michelsen SI, Nystrand M, Colver A, Thyen U. Predictors of parent-reported quality of life of adolescents with cerebral palsy: A longitudinal study. Res Dev Disabil 2017; 62:259-270.

29. Tu AW, Watts AW, Chanoine JP, Panagiotopoulos C, Geller J, Brant R, Barr SI, Mâsse L. Does parental and adolescent participation in an e-health lifestyle modification intervention improve weight outcomes? BMC Public Health 2017; 17:352.

30. Zilanawala A, Sacker A, Kelly Y. Longitudinal latent cognitive profiles and psychosocial well-being in early adolescence. J Adolesc Health 2017; 61(4):493-500. 
31. Colver A, Rapp M, Eisemann N, Ehlinger V, Thyen U, Dickinson HO, Parkes J, Parkinson K, Nystrand M, Fauconnier J, Marcelli M, Michelsen SI, Arnaud C. Self-reported quality of life of adolescents with cerebral palsy: a cross-sectional and longitudinal analysis. Lancet 2015; 385(9969):705-716.

32. Nelson PA, Caress AL, Glenny AM, Kirk SA. 'Doing the "right" thing': how parents experience and manage decision-making for children's 'normalising' surgeries. Soc Sci Med 2012; 74(5):796-804.

33. Barbosa PV, Wagner A. A construção e o reconhecimento das regras familiares: a perspectiva dos adolescentes. Psicologia em Estudo 2014; 19(2):235-245.

34. Chiang EDO, Baker ML, Figueroa-Downing D, Baggio ML, Villa, Luisa EN, Craig JH, Robert AB, Evans DP. "Those who love, vaccinate": parental perceptions of HPV vaccination. Journal of Human Growth and Development 2015; 25(3):341-350.

35. Terres-Trindade M, Mosmann CP. Discriminant profile of young internet dependents: the role of family relationships. Paidéia 2015; 25(62):353-361.

36. Barbosa PV, Wagner A. A construção e o reconhecimento das regras familiares: a perspectiva dos adolescentes. Psicologia em Estudo 2014; 19(2):235-245.

37. Faler CS, Câmara SG, Aerts DR, Alves GG, Béria JU. Family psychosocial characteristics, tobacco, alcohol, and other drug use, and teenage pregnancy. Cad Saude Publica 2013; 29(8):1654-1663.

38. Monte FFC, Sampaio LR. Práticas pedagógicas e moralidade em unidade de internamento de adolescentes autores de atos infracionais. Psicologia: Reflexão e Crítica 2013; 25(2):368-377.

39. Freitas AF, Seidl EMF. Estudo sobre a heteronomia na assistência em saúde a crianças e adolescentes com necessidades especiais. Rev. bioét 2011; 19(1):119-140.

40. Brody GH, Yu T, Beach SR, Kogan SM, Windle M, Philibert RA. Harsh parenting and adolescent health: a longitudinal analysis with genetic moderation. Health Psychol. 2014; 33(5):401-409.

41. Verberne LM, Kars MC, Schouten-van Meeteren AY, Bosman DK, Colenbrander DA, Grootenhuis MA, van Delden JJ. Aims and tasks in parental caregiving for children receiving palliative care at home: a qualitative study. Eur J Pediatr 2017; 176(3):343-354.

42. Cianchetti C, Messina P, Pupillo E, Crichiutti G, Baglietto MG, Veggiotti P, Zamponi N, Casellato S, Margari L, Erba G, Beghi E. The perceived burden of epilepsy: Impact on the quality of life of children and adolescents and their families. Seizure 2015; 24:93-101.

43. Lee SJ, Li L, Thammawijaya P. Parenting styles and emotional intelligence of HIV-affected children in Thailand. AIDS Care 2013; 25(12):1536-1543.
44. Rodenburg R, Meijer AM, Scherphof C, Carpay JA, Augustijn P, Aldenkamp AP, Dekovic M. Parenting and restrictions in childhood epilepsy. Epilepsy Behav 2013; 27(3):497-503.

45. Roelofs J, Meesters C, Ter Huurne M, Bamelis L, Muris P. On the links between attachment style, parental rearing behaviors, and internalizing and externalizing problems in non-clinical children. Journal of Child and Family Studies 2006; 15(3):331-344.

46. Parvizy S, Ahmadi F. A qualitative study on adolescence, health and family. Ment Health Fam Med 2009; 6(3):163-172.

47. Frani T, Kardum G, Prižmi IM, Pavleti N, Mar inko D. Parental involvement in the war in Croatia 1991-1995 and suicidality in Croatian male adolescents. Croat Med J. 2012; 53(3):244-253.

48. Bello BM, Fatusi AO, Adepoju OE, Maina BW, Kabiru CW, Sommer M, Mmari K. Adolescent and parental reactions to puberty in Nigeria and Kenya: A cross-cultural and intergenerational comparison. $J$ Adolesc Health 2017; 61(4S):S35-S41.

49. Khatun M, Al Mamun A, Scott J, William GM, Clavarino A, Najman JM. Do children born to teenage parents have lower adult intelligence? A prospective birth cohort study. PLoS One 2017; 12(3):e0167395.

50. Saltzburg S. Learning that an adolescent child is gay or lesbian: the parent experience. Social Work 2004; 49(1):109-118.

Article submitted 31/10/2017

Approved 26/02/2018

Final version submitted 18/06/2018 
